e ISSN-0976-6847

\title{
Research Article: Paddy cultivation technology for utilization comportment of farmers
}

Article Chronicle : Received : 01.12.2014;

Revised : 24.12.2014;

Accepted :

10.01.2015

Key Words :

Behaviour, Paddy growers, Technology utilization
Author for correspondence :

\section{H.N. MAHERIYA}

Department of Extension Education, B. A. College of Agriculture, Anand Agricultural University, ANAND (GUJARAT) INDIA Email: hiten2889@ gmail.com See end of the article for authors' affiliations

\section{H.N. MAHERIYA*, J.K. PATEL AND R.C. PATEL}

SUMMARY : Using functional technology, majority of the farmers had average to above average technology utilization behaviour in paddy farming. All the variables except experience in paddy farming, extension participation and risk orientation, all other independent variables showed significant influence in determination of technology utilization behaviour. Annual income and scientific orientation had shown maximum influence on technology utilization behaviour. Annual income contributed 49.40 per cent total variation in predicting technology utilization behaviour and total joint contribution of all independent variable together contributed 62.40 per cent variation in determining technology utilization behaviour. As far as direct, indirect and substantial effects are concerned age was key variables in exerting positive and direct effect on technology utilization behaviour in paddy growers. Whereas, annual income had positive and highest indirect effect and economic motivation, animal possession and annual income were the key variables in determination of substantial indirect effect on technology utilization behaviour of paddy growers.

How to cite this article : Maheriya, H.N., Patel, J.K. and Patel, R.C. (2015). Paddy cultivation technology for utilization comportment of farmers. Agric. Update, 10(1): 23-26. 